\title{
Proceeding
}

Supplementary Issue: Winter Conferences of Sports Science. Costa Blanca Sports Science Events, 25-26 January 2019.

Alicante, Spain

\section{Dribbling in football: Confronting learning theories}

\author{
LUIGI GIORDANO ${ }^{1} \triangleleft$, ARIO FEDERICI ${ }^{2}$, MANUELA VALENTINI ${ }^{2}$, FRANCESCA D'ELIA ${ }^{1}$ \\ ${ }^{1}$ University of Salerno, Italy \\ 2University of Carlo Bo of Urbino, Italy
}

\begin{abstract}
The football game is the most beloved sport among society, especially for its emotional and recreational worthiness. Dribbling is the most important ability. It is intended to be as the capability of keeping the ball afloat preventing it from touching the ground by using the two lower limbs. The most time the ball lingers afloat, the highest level the doer shows to have achieved. The main point of this research is to spot the most adequate educative method in dribbling. By confronting two different learning methods, I have tried to develop a way of making headways in the above process. On the one hand the cognitive approach in the scientific paradigm turns out to work with a fabricated set of rules within which the little boy must move, whereas in the eco-dynamic approach the heuristic way of learning is followed. The results give out two solutions: the first one shows an increasing ability pursued by gradual repetitions, beginning with a low degree of complexity up until a major difficulty; the last one aims at getting gratification on "no ruling" ground. In the first case, the players must stick to the coach's orders and timing conditions. In the second one the doers are just given the space and tools, neither timing nor conditions are set. They only have to express themselves as much as they like. Both methods grasp to the ordinary educational system. Key words: Dribble; Methodology; Children; Ball; Training.
\end{abstract}

Cite this article as:

Giordano, L., Federici, A., Valentini, M., \& D'Elia, F. (2019). Dribbling in football: Confronting learning theories. Journal of Human Sport and Exercise, 14(2proc), S228-S232. doi:https://doi.org/10.14198/ihse.2019.14.Proc2.10

Corresponding author. University of Salerno, Italy.

E-mail: I.giordano74@studenti.unisa.it

Supplementary Issue: Winter Conferences of Sports Science. Costa Blanca Sports Science Events, 25-26 January 2019. Alicante, Spain.

JOURNAL OF HUMAN SPORT \& EXERCISE ISSN 1988-5202

(c) Faculty of Education. University of Alicante.

doi:10.14198/jhse.2019.14.Proc2.10

S228 | 2019| Proc2| VOLUME 14

C 2019 University of Alicante 


\section{INTRODUCTION}

We let kids play but we do not try to change football into an exact science, because it is not a ruleset game by Massimiliano Allegri, Juventus.com, 2018.

Many studies point out that football is the most played game because it is both recreational and emotional. Among the numerous skills required, the most important one is the ability to dribble, that is to keep the ball lingering in the air preventing it from falling mostly by using lower limbs. This ability indicates how skifful a player is and consist in doing as many dribbles as possible. (Altavilla, Raiola, 2018).

Dribbling is essential in football, but it is true that football players hardly ever dribble on the pitch because it requires coordination and focus. (Valentini, et al., 2018).

Dribbling actually means "touching" the ball with the foot, or any other part of the body except from hands and arms preventing it from falling down.

Being able to dribble means "controlling" the ball.

In order to keep the balance, one has to slightly lean forward and bend their arms. The knee works like a spring. (Raiola, et al., 2015).

The foot can only touch the ball during its descent, and in order to get the perfect touch, there has to be an angle of $95^{\circ}$ between the toe and the knee.

The eye is fixed onto the ball because it leads all the movements. Both feet have to touch the ball.

Dribbling can be done with the knee and the head, therefore there are a lot of combinations. (Raiola, Di Tore, 2017).

When dribbling with the head, one has to keep an almost upright position, the head has to lean a little backwards, the legs have to be straddled and the arms spread out in order to keep the balance. The forehead has to hit the ball, the eyes stare at it and the body bounces in order to help hit the ball. (Raiola, D'Isanto, 2016).

The instructor assesses all the improvements done in a certain fixed time. His main task is to make a prospectus of the improvements done by the kids and to create training sessions which will help them achieve the fixed results. (Raiola, 2011).

This study aims at finding the best way to improve the dribbling performance. This is the comparison of the educational theories applied in dribbling teaching-learning in football through the research of the documentary archives. The results delineate the scientific paradigm of the cognitive approach with the teaching method prescribed versus the dynamic ecological approach with the method of ecologic learning. The theorical results highlight two solutions: the first is the educational method of gradual and progressive repetitions with the initial modalities of low difficulty to progressively reach the highest result; the second is the method of absolute freedom without any prescription with the attainment of gratification. The first one involves the mere execution of the coach's orders with the exact description of the sequence and timing of repeated exercises, whereas 
the second just fixes the environment and the tools for the educational activities. Each solution has got the details of ways how to perform the educational activities. (D'elia, 2019).

\section{METHODS}

During the first phase of this path, the kids will simply have to make 1 dribble in order to get acquainted both with the ball and the correct movements. In fact the ball is simply made to hit the ground with their hand and then kicked once, so that it can be grabbed again. (Di Tore, Raiola, 2012).

As the trainings proceed, the single dribble becomes multiple so as to switch to using both feet. (Raiola, 2012).

The next step is to accustom the child to raise the ball directly with his feet and urge him into performing as many dribbles as possible. (Bignami, Mingardi, 2017).

The proposed result is to reach a minimum of 15 dribbles and integrate the touch with the foot with the ones with head, shoulders, chest, symptom of a perfect coordination of the whole body. The method with which we will face this experimentation will be the direct observation of what is expressed in this area by the children. (D'lsanto, 2016).

To make learning mechanisms easier it is necessary to extend the training session so to improve the dribbling quality. The basic training cache is about the groundings of the football game which let the kids improve their skills day by day: ball keeping (a fourth measure as a start) through which the little boy learns to hold the ball between the tip of their foot and the external side of this latter; passing the ball towards the same direction by using both the right foot and the left one; kicking with the outside of the foot; various exercises concerning the mastering of the football; standstill hopscotch; walking hopscotch; one-go processing (i.d. jumping onto the ball); back and forth processing (the ball must be touched by the front sole foot) that is useful to gain stability while dribbling; spinning the ball by the tip of the feet; toe-heel; inside-outside of the foot; moving the ball with the inner and outer side of the foot; do it again while jumping; dribbling through the cones; ballkeeping through the bars; passing the ball after the speed agility; stopping the ball by the foot sole; kicking against the wall following a certain rhythm; one against one; three against two; keep-away; ball-keeping amidst cones and opponents trying not to reverse one into each other; kicking the ball by dropkick; feints; different ways of lifting the ball. (Benini, Faccioli, 2016).

The aim is not to stress the players but to let them have fun. They work hard but by working hard they get excited by Gasperini, an Italian football trainer, 2018.

The methodical training sessions allow the kids to acquire such an ability that all those who do not follow the same training pattern will never be able to get. This is what this research is worth for: achieve coordination little by little. (Raiola, 2015).

Aesthetics count but a kick leading to a goal is what counts more by Del Piero, an ex italian football player, 2012. 


\begin{tabular}{|l|l|}
\hline Coordination exercises & Ball touch smoothing \\
\hline Speed agility & Ball conduction \\
\hline Obstacles & Passages \\
\hline Kicks & Ball-mastering exercises \\
\hline Feints & Hopscotch \\
\hline Motoric tracks & Scales \\
\hline Hopscotch (world) & Ball touching \\
\hline Rings & Toe-heel, inner-outer side of the foot \\
\hline Rope & Sole foot exercises \\
\hline Bounces & Dribbling through cones \\
\hline Backflip & Ball stopping by the sole of the foot \\
\hline Rolling & Ball against the wall \\
\hline Crawling & Lifting the ball over the obstacles \\
\hline Running exercises & Dropkick exercises \\
\hline
\end{tabular}

\section{RESULTS}

In the previous paragraphs we have gone through a process with different grades of difficulty. As a start the kids have been taught to easily lift the ball with their hands up until the moment when they have been asked to do it just with their feet. As the first weeks went by they "have made friends" with the ball which would accompany them through the upcoming months. (Altavilla, et al., 2015).

On the other hand there is a different way of proceeding, letting the kids complete freedom. Although the kids are not given any prescriptions, the final results stays unaltered: they have to achieve the best quality of dribbling. (Altavilla, Di Tore, 2016).

The on-field findings point out that those who have undergone the first model of learning have acquired a greater capability than those who have been let completely free. (Polidoro, et al., 2013).

The result is random, the performance is not by Zeman, an Italian football trainer, 2010.

This study shows how much the help of an expert is required in teaching a baby boy the dribbling techniques when failure is not permitted. (Raiola, 2017).

\section{REFERENCES}

Altavilla, G., Di Tore, P.A. (2016). Physical education during the first school cycle: A brief social psychopedagogical summary. Journal of Physical Education and Sport, 16 (2), pp. 340-344.

Altavilla, G., Furino, F., Marika, D.P., Raiola, G. (2015). Physical skills, sport learning and socio-affective education [Fizičke vještine, sportsko učenje I društveno-afektivno obrazovanje] Sport Science, 8, pp. 44-46.

Altavilla, G., Raiola, G. (2018). Physiological effects of warm-up and problems related to team sports, Sport Science, 11, pp. 83-88.

Benini C., Faccioli L. (2016). Una nuova scuola calcio. Verona: QuiEdit.

Bignami L., Mingardi M. (2017). A scuola di calcio. Recco (GE): Edizioni Correre. 
D`Elia, F. (2019). The training of physical education teacher in primary school. Journal of Human Sport and Exercise, 14(1proc), S100-S104. https://doi.org/10.14198//hse.2019.14.Proc1.12

D'Isanto, T. (2016). Pedagogical value of the body and physical activity in childhood [Pedagoška vrijednost tijela i tjelesne aktivnosti u djetinjstvu]. Sport Science, 9, pp. 13-18.

Di Tore, P.A., Raiola, G. (2012). Exergame-design and motor activities teaching: An overview of scientific paradigms on motor control, Mediterranean Journal of Social Sciences, 3 (11), pp. 119-122.

Polidoro, L., Bianchi, F., Di Tore, P.A., Raiola, G. (2013). Futsal training by video analysis, Journal of Human Sport and Exercise, 8 (2), pp. 290-296. https://doi.org/10.4100/jhse.2012.8.Proc2.31

Raiola, G. (2015). Sport skills and mental health, Journal of Human Sport and Exercise, 10, pp. 369-376. https://doi.org/10.14198/ihse.2015.10.Proc1.27

Raiola, G. (2012). Motor learning and didactics into physical education and sport documents in middle school-first cycle of education in Italy, Journal of Physical Education and Sport, 12 (2), pp. 157-163.

Raiola, G. (2017). Motor learning and teaching method, Journal of Physical Education and Sport, 17, pp. 2239-2243.

Raiola, G. (2011). Study between neurophysiological aspects and regulation documents on preschool in Italy, Journal of Physical Education and Sport, 11 (1), pp. 42-47.

Raiola, G., Altavilla, G., Filippo, G.P. (2015). Effects of physical activity and sports in the reduction of stereotypy in blind subjects [Učinci tjelesne aktivnosti i sporta u smanjenju stereotipa kod slijepih subjekata] Sport Science, 8, pp. 52-55.

Raiola, G., D'isanto, T. (2016). Assessment of periodization training in soccer. Journal of Human Sport and Exercise, 11, pp. 267-278. https://doi.org/10.14198/ihse.2016.11.Proc1.19

Raiola, G., Di Tore, P.A. (2017). Motor learning in sports science: Different theoretical frameworks for different teaching methods [Motoričko učenje u sportskoj znanosti: Različiti teorijski okviri za različite metode poučavanja] Sport Science, 10, pp. 50-56.

Valentini, M., Riccardi, F., Raiola, G., Federici, A. (2018). Educational research: Motor area and relational area during children's personality development, Journal of Physical Education and Sport, 18, pp. 2157-2174.

\section{(9)}

This work is licensed under a Attribution-NonCommercial-NoDerivatives 4.0 International (CC BY-NC-ND 4.0). 